\title{
Antimicrobial Potentials of Canna Indica Linn. Extracts against selected Bacteria.
}

\author{
Abhishek Gaur*, Monalisa Boruah and Durvesh K. Tyagi \\ Department Of Chemistry, Shri Jagdish Prasad Jhabarmal Tibrewala University, \\ Vidyanagari, Jhunjhunu, Rajasthan - 333001
}

\begin{abstract}
To obtain much better information about the medicinally use of various extracts of Canna indica Linn. investigations were conducted. The extract shows good antibacterial activity against Staphylococcus aureus, Bacillus subtilis and mild active against Escherichia coli. The results show the inhibition of microbial growth decreased with decreasing in concentration of the plant extracts. The extract material from the rhizomes of the Canna indica shows good antimicrobial activity.
\end{abstract}

Keywords:

1. Canna Indica Linn

2. Various extracted material

3. Antimicrobiological activity

\section{Introduction}

The plant Canna indica Linn. (Syn. Canna orientalis Roscoe) belongs to Cannaceae family. Knows as Sabbajayain Hindi, it is called Devakuli in sankrit ${ }^{1}$. It is also known as Indian shot or Canna lily. Stem 0.9-1.2m high, leaves $15-45 \mathrm{~cm}$ by $10-20 \mathrm{~cm}$, lanceolate to ovate, oval or almost orbicular, caudate acuminate, veins arching, sheath open above. Flower rather distant, $5-6.5 \mathrm{~cm}$ long, bracts, 1.3-2.5 cm, oblong membranous. Seeds very many, globose, black, Shining. The root is given as a demulcent and stimulant and used as a diaphoretic in fevers and dropsy ${ }^{2}$. Antimicrobial study of the essential of the plant also have been done by Indrayan et.al ${ }^{3 .}$

\section{Material And Method}

Authenticated rhizomes of Canna indica were procured from Haridwar and authenticity verified from F.R.I. Dehradun. Specimens have been deposited in the herbarium of Plant Medicine Section of the Botany Divison of University. The procured rhizomes were washed with luke warm water and dried in shade.

\section{Extraction Of Material In Solvent Of Different Polarity \\ Extraction in petroleum ether $\left(40-60^{\circ}\right)$}

$100 \mathrm{~g}$ rhizome was crushed and kept in sufficient quantity of petroleum ether in a Soxhlet extractor for 72 hours. A decoction of Yellowish colour was collected and fresh quantity of petroleum ether was added again and kept again for 72 hours. The process was repeated till the extract become colourless. All the extracted solutions were mixed and petroleum ether was separated under reduced pressure. A Yellowish brown viscous oily material was obtained.

\section{Extraction in diethyl ether}

Similar procedure, as for petroleum ether, was carried out. Yellowish brown viscous oily material was obtained.

\section{Extraction in ethanol}

Similar procedure, as for petroleum ether, was carried out. Dark brown solid material was obtained.

\section{Extraction through water}

$100 \mathrm{~g}$ of the crushed rhizome was boiled with doubly distilled water for $1 \mathrm{~h}$. The extract was filtered and water was evaporated. A dark brown solid material was obtained.

\section{Results And Discussion}

Extracted material was studied against gram +ve bacteria i.e. Staphyococcus aureus, Bacillus subtilis and gram -ve bacteria i.e. Escherichia coli . Results are complied in the following 
Table:-1

\begin{tabular}{|l|c|c|c|c|c|}
\hline Antibacterial activity of the four extract from the rhizomes of Canna indica Linn \\
\hline \multirow{2}{*}{ Microorganism } & \multicolumn{3}{|c|}{ Inhibition zone } & \multirow{2}{*}{ Standard* } \\
\cline { 2 - 5 } & Petroleum ether & Diethyl ether & Ethanol & Water & Nil \\
\hline Staphylococcus aureus (+) & 9.0 & 7.0 & Nil & Nil & Nil \\
\hline Bacillus subtilis (+) & 2.0 & 8.5 & Nil & Nil & 36 \\
\hline Escherichia coli (-) & 0.01 & 0.04 & \multicolumn{5}{|l}{} \\
\hline *Standard was chloramphenicol, $30 \mu \mathrm{g} / \mathrm{disc}$
\end{tabular}

The petroleum ether and diethyl ether extracts have shown promising inhibitory action against all studied microorganism (Table-1). Growth of Staphylococcus aureus is moderately inhibited. The bacterium causes secondary infections and food poisoning ${ }^{4}$. Growth of Escherichia coli is also inhibited, though mildly only. E. coli is a well known member of gastrointestinal tract flora and causes gastroenteritis in infants and children $^{5}$ and urinary tract infections ${ }^{6}$. Growth of Bacillus subtilis is inhibited strongly. B. subtilis is an opportunist bacterium and can cause egg infection and septicaemia ${ }^{7}$, can contaminate blood transfusion bottle and, thus, homolyse the blood. Several episodes of food poisoning have also been attributed to B. subtilis.

Present study suggests that the extracted materials from the rhizomes of Canna Indica Linn. have potential antibacterial activity which can be further used in the pharmaceutical formulation, after due clinical tests. Use in agriculture is also well concluded.

\section{References}

[1]. Pullaiah T., (2006), Encyclopaedia of World Medicinal Plants, Regency Publication, New Delhi, India, I, 421.

[2]. Kirtikar K.R. and Basu B.D., (1970), Indian Medicinal Plants, $2^{\text {nd }}$ Ed., Lalit Mohan basu, Allahabad, IV, $2450-2452$

[3]. Indrayan A.K.,Bhojak N.K., (2011) Kumar N., Shatru A. and Gaur A., Ind. J. of Chem., 50B, 1136-1139

[4]. Loir Y.L., Florence B. and Gautier M., Genet. and Mol. Res., 2, 63 (2003).

[5]. Dadie A, Tagro G., Anin L.O., Dako E., Dje M. and Dosso M., European J. Sci. Res., 39, 143 (2010).

[6]. Tena D., Gonzalez-Praetorius A., Saez-Nieto J.A., Valdezate S. and Bisquert J., Emerging Infectious Diseases, 14, 1163 (2008).

[7]. Logan N.A., J. Med. Microbiol., 25, 157 (1988). 